\title{
Ownership, Control, Agency and Residual Claims in Healthcare: Insights on Co-operatives and Non-profit Organisations
}

\section{Introduction}

Dating from at least the time of Adam Smith, academics have sought to develop a "theory of the firm" that is sufficiently general enough to capture all of the manifestly different forms into which individuals (voluntarily) organise their transactions. Such a theory would also explain governance arrangements used to both set the 'firm's" ${ }^{\text {' }}$ strategy and agenda, and monitor and enforce the performance of those charged with carrying it out. It could also point to the most appropriate external monitoring for certain organisational forms.

Much of the early historic research on the agency theory of the firm and the related governance arrangements derives from Berle \& Means's (1937) separation of ownership and control, and the management of the ensuing moral hazard risks. More recently Grossman \& Hart's (1986) incomplete contracting theories is used as a means of explaining the observed nexus between the boundaries of a firm, the identity of its owners and the allocation of both formal and informal control rights (Aghion, Bloom \& Van Reenen, 2014; Bolton, 2014; Gibbons \& Roberts, 2012). At the core of theories based upon both agency and incomplete contracting concepts is the bundling (either ex ante or ex post) of ownership of residual assets and income streams with the ability to exercise residual control rights (Dessein, 2014).

Yet, firms with nonstandard ownership arrangements, such as non-profits and cooperatives, have always engaged in economically significant activities, and are assuming growing importance in the policy context (Hansmann, 2008; 2012). Their distinguishing feature is that, to some degree or other, they compromise the fundamental nexus between residual ownership and the exercise of control rights upon which most theories of the firm are

In this paper we take a broad view of what constitutes 'the firm' extending from for-profit organisations to those with a nonprofit or mission-based focus, including cooperatives. 
predicated. Governments - which exhibit arguably the most nonstandard models of ownership and control allocation (Moe, 2012) - are experimenting with a range of different institutional arrangements for delivering taxpayer-funded services, and the contracts to fund and hold these nonstandard entities (e.g. State-Owned Enterprises - Kowalski, Büge \& Sztajerowska, 2013; Public-Private Partnerships - Iossa \& Martimort, 2015). Contracting-out of governmentfunded health care to non-profit firms or collectives of independent practitioners affiliated as provider co-operatives is a prominent example (Howell \& Cordery, 2013).

The growing interest in nonstandard entities (see Sacchetti and Tortia, 2015; Thornton and Cave, 2010) begs the question of how parties seeking to interact with them should structure their transactions, and how the firms themselves and their stakeholders should seek to structure governance arrangements so as to achieve their individual and joint best possible outcomes. Policy-makers and regulators also need to be aware of the efficiency consequences of these arrangements (Kanaya et al., 2015; Thornton and Cave, 2010).

However, these firms have not featured prominently in theory of the firm research. Gibbons \& Roberts (2012, pp 6-7) observe: "legislatures, government bureaus and departments, the courts, political parties, clubs, co-operatives, mutual, family firms, stateowned enterprises, charities and not-for-profits, hospitals, universities and schools all ... deserve more attention than they have received' in Organizational Economics $(\mathrm{OE})$ research. In part, this may be a function of the novelty of the $\mathrm{OE}$ approach, which to date has provided a number of basic qualitative insights, but has yet to link "ownership or integration decisions to variables that can be quantified ... (or)... provide a framework for identification” (Aghion, et al. (2014, p 10). In similar vein, Bolton (2014, p 77) observes the lack of simple quantifiable methodologies for making agency, limited commitment, information and control theories "more operational". But if it has so far proved difficult to operationalize quantitative OE research on standard shareholder-owned firms, how can we even begin to apply the conceptual insights of this literature to firms with nonstandard ownership forms?

This paper rises to the challenge posed by OE researchers from the positive perspective of identifying how, in nonstandard firms, elements of residual ownership and control are 
precluded from being bundled into a single decision-maker. Nonstandard firms are distinguished from firms integrating residual ownership and control that have to date characterised $\mathrm{OE}$ research. We do not replicate prior normative pursuits of an optimal scope of integration of activities to define the boundaries of a firm. Rather, we systematically identify and catalogue these differences as a first step towards rendering tractable for empirical analysis, the extremes of heterogeneity and complexity observed in practice. Drawing upon both agency and incomplete contracting theories, we develop a multi-dimensional taxonomy classifying the allocation of residual ownership and control rights that is sufficiently broad enough to encompass both standard shareholder-owned and non-standard firms. The taxonomy can then be used both in case study analysis of the artefacts influencing decisions in individual firms, as a basis for classifying firms for much broader comparative empirical analysis and for testing hypotheses.

The paper proceeds as follows. In Section 2, we survey the literature on the theory of the firm, and how it has been applied to provide insights into firms with nonstandard relationships between residual ownership and control. Drawing on that literature we then develop the taxonomy of dimensions along which the differences between standard shareholder-owned firms and firms with nonstandard ownership arrangements might be expected to lead to materially different contractual options and outcomes (see Figure 3). In Section 4, we demonstrate the use of the taxonomy to highlight important differences between standard shareholder-owned firms, supplier-owned co-operatives and classic non-profit charities in the New Zealand primary health care sector. We illustrate how important ownership and control differences between co-operatives and the charitable trusts indicate the need for different contractual arrangements, both within the firms' governance structures and, importantly, in external government contracts for service provision. Section 5 concludes by identifying how the taxonomy can be used for future empirical research. 


\section{Theoretical Framework}

\subsection{A Contractual Foundation?}

Historic theories of the firm are agency-based and derive from Berle \& Means (1937). Yet, most modern economics-based theories derive from Ronald Coase's (1937) seminal paper characterising the firm's boundaries as delineated by transactional exchanges outside the market. He argued that activities would be undertaken within a firm whenever the costs of using markets were greater than the costs of using direct authority. Alchian and Demsetz (1972) instigated a new line of inquiry into the nature of contracts within the firm in proposing that when there is joint input or team production, the firm offers a more cost-effective means of monitoring.

Whilst agreeing that contractual exchange within firms was important, Jensen and Meckling (1976) found Alchian and Demsetz's (1972) emphasis on monitoring too restrictive, calling for a more nuanced theory. Jensen and Meckling (1976) recognised that most organisations are legal fictions serving as a nexus for a set of contracting relationships among individuals, as owners of labour, material, or capital inputs, or as consumers of output. They therefore postulated that the firm's behaviour will reflect how the conflicting objectives of those individuals play out via contractual relations: in particular, the costs of agency (arising when the interests of the agent (manager) diverge from those of the principal (owner)), and the costs of risk-bearing associated with the ways by which the owners of capital (debt or equity) supply.

Fama and Jensen (1983a; 1983b) advanced the theory further, to explain the existence of firms where there were no defined equity owners. These 'non-owned' - or non-profit - firms are characterised by the 'non-distribution constraint' prohibiting distribution of the firm's residual earnings to the (vested) interests exercising control over its decision making (Hansmann, 1980). The non-distribution constraint unbundles the residual control and residual risk-bearing functions of shareholder-owned firms. They contended that in all firms, decisionmaking occurs through structures separating ratification and monitoring of decisions ("governance") from initiating and implementing the decisions ("management"). In a non- 
profit firm, separating the decision management from decision control can offer greater assurances to donors and beneficiaries that decision managers will be constrained against misappropriation of resources (Fama and Jensen, 1983b).

Fama and Jensen (1983b) also applied their framework to professional partnerships and mutual structures. Decision control in a mutual, where customers are the residual risk bearers, can be exercised by each claim holder redeeming his/her claim. Partnerships eschew the shielding of limited liability associated with shareholder-owned firms, but nonetheless rely upon the partners being residual claimants to discipline decision-making. Fama and Jensen's distinction between the elements of decision management and decision control drew into sharp relief the need for aligning the various agency contracts to the various pecuniary interests of the residual risk bearers.

In contrast, however, Hansmann (1996) contended that firm's owners will be those stakeholders ('patrons') with the lowest combined costs of ownership and market contracting. Ownership costs are principally internal costs associated with separation of risk bearing, decision control and decision bearing, with the costs of market contracting are principally the costs of transacting in the market with internal (e.g. labour) and external (e.g. suppliers, customers) entities. Hansmann (1996) preserved the concept of the firm as a legal fiction separating patrons are separated into consumers and suppliers of labour, materials and capital (both equity and debt). Where shares in the firm are freely tradable, he contended that the most efficient ownership forms will emerge endogenously. If a less-efficient patron class owns the firm, then the more efficient interests will either take it over or create a more efficient firm that, through competition, will drive the less efficient one out of the market.

In this vein, Hansmann (1996) contended that firms constrained by the non-distribution would emerge endogenously when the costs of maintaining individual ownership interests outweigh the costs of forgoing these interests. These firms would instead rely upon individuals bound only by fiduciary duties to undertake control of the firm. He maintained a distinction between truly 'non-owned' firms and those (e.g. co-operatives, clubs and mutuals) where specific patrons held similar controlling interests to shareholder-owner patrons, even though 
their claims on residual assets and income streams were somewhat attenuated. For example, he distinguishes between co-operatives where supplier-members are the controlling interests (for example 'supplier-controlled" co-operatives such as Independent Practitioner Associations co-ordinating firms of doctors providing primary healthcare) and those where consumers hold sway ("consumer-controlled" co-operatives such as a health clinic run by a trade union for its members, or a child care co-operative run by parents). This distinction is related to the duty of the decision-makers as fiduciaries to operate the firm in the specific interests of that patron group.

Applying Hansmann's reasoning, if the risks (losses) potentially arising as a consequence of the (incomplete) contracts between the affected stakeholders and the firm are sufficiently large, then one would expect the stakeholders to be able to resolve the problem by assuming ownership themselves. Accordingly, the right to appoint members of the decision control body emanates from their role as residual claimants, not as stakeholders in any other trading sense. But if, in the trade-off between costs and ownership, no ownership is the most efficient arrangement, then the governance arrangements of the non-owned firm should be aligned with the interests of beneficiary-patrons (either customers - e.g. patients - or suppliers - e.g. donors) who would otherwise have been the firm's legal owners (Howell \& Cordery, 2013).

By considering both the costs of ownership and the costs of market contracting, Hansmann's schema for firm ownership coalesced the literature on agency theory used by Meckling, Fama and Jensen with the body of incomplete contracting literature deriving from Grossman and Hart (1986). Grossman and Hart (1986) observed that contracts cannot specify all states of nature or all actions in advance (e.g. because agents are boundedly rational), recognising that some states of nature or actions cannot be verified by third parties ex post, and are therefore not ex ante contractible either. When a contract negotiated ex ante inevitably allows discretion over asset use, then the 'owner' is the party with the residual rights of control who decides how to fill the contractual 'holes' relating to the asset. The optimal governance structure is one which maximises ex ante surplus given that contracts are incomplete. When 
contracts are unenforceable and ex post renegotiation must be relied upon to 'fill the contractual holes', the contractual incompleteness leads to efficiency losses. Optimal governance arrangements - that specify the allocation of control rights to assets exposed by the incomplete contracts - will be those that provide the incentives that best minimise these losses.

Extensions of Gross and Hartman continue to provide insights into aspects of the theory of the firm, particularly addressing the question of vertical integration that first inspired the authors. Dessein (2014) identifies two strands addressing this question: one where noncontractible actions are treated in a similar fashion to 'effort' in the moral hazard literature; and one where the question of 'who' takes the noncontractible actions (owners, or their manager-agents) becomes a choice variable.

Dessein (2014) surveys models where actions are never contractible, either ex ante or ex post, and building on Hart \& Holmstrom (2010), offers a model where managers' coordination function rationalises the trade-off between agents' motivation (favouring nonintegration) and co-ordination (favouring integration). Whilst integration allows owners to take advantage of co-ordination benefits, it worsens the information transfer from manager-agents to owner-principals, and inhibits adaptation to local knowledge observed only by the manageragents. Aghion et al. (2014) distinguish between formal authority which can be allocated contractually, and real authority which resides in the better-informed party. This distinction helps explain the allocation of authority in multi-layer hierarchies, the relationship between delegation and trust, and the relationship between decentralization and characteristics such as the firm's age, firm heterogeneity and the degree of competitiveness in the sector and how close to the technological frontier the firm is. However, the models giving rise to these insights all presume the bundling of residual ownership and control, and the profit maximisation objective of the owner.

For a fully comprehensive theory of the firm encompassing nonstandard firms to be developed, it would seem necessary to tease out the differences between the different elements of residual ownership and residual control in these firms, the contractibility (or otherwise) of the different rights, the objectives of the individuals on whom they are conferred and the 
contractual interactions into which they enter. The firm should be considered not a nexus of contracts (Jensen \& Meckling, 1976), but a nexus for contracts (Hansmann, 2008) where its boundaries are determined by the relative efficiency of allocating the separate and numerous residual rights of ownership and control to different parties (Evans et al., 2012). Indeed, one of the motivations for the formation of non-profit firms - the limits to the ability of third parties to assess service quality in 'trust goods' such as health care which is observed frequently in practice - is a non-ownership based strategic solution to a problem of noncontractibility when residual assets are negligible and information asymmetries prevail (Ben-Ner, 1986; Hansmann, 1996). Whilst only recently acknowledged as an explicit strategic option (Glaeser \& Schleifer, 2001), it has sat at the core of the theory posited by Arrow (1963) to explain the non-profit objective observed by medical practitioners that is arguably as old as the medical profession itself.

\subsection{Rights to Assets and Income Streams}

Moving the theory of the firm onwards to account for firms with nonstandard ownership, it is necessary to examine first how ownership and control are divided and separately contracted. This allows us to identify how dimensions of non-ownership may affect bargaining behaviour when the effects of contractual incompleteness manifest themselves.

Hart \& Moore (1996) examine the co-operative form that was (at the time) commonly observed amongst stock exchanges. They note (p56) that the residual rights of control of the assets of exchanges are held "by the members, who take decisions democratically, on a onemember-one-vote basis" even though the residual assets are commonly-held with no explicit residual claims, and annual residual earnings (profits) are disbursed in proportion to trading activity.Contractual arrangements are used to assign control rights in a different proportion to residual ownership claims, so that the markets for firm control are at variance to the markets for ownership of the residual assets and income streams. Although the rights of residual control are not allocated proportionately vis-à-vis the distribution of income and assets, there is a direct correlation between 'ownership' and 'control' rights. 
Where are the residual rights of control of the assets vested when firms have no owners? The self-evident answer is 'nowhere'. In the first instance, all else held equal, the governance arrangements of non-owned firms must identify and explicitly contractually assign as many of the control rights as it is technically feasible. Ex ante assignment is necessary as it is not possible to assume that non-contracted control rights will automatically vest in the appropriate party when their value is revealed. Whereas it is axiomatic in owned firms that non-specified rights have clear owners which enables loose specifications (and hence flexibility in contracts), such flexibility is unwise in non-owned firms, as they lack owners to take responsibility for the future contracting of the rights that are revealed. Thus, both the governance arrangements and the contracts associated with contracting with non-owned firms will necessarily be more complex than observed in forms where ownership is clearly assigned. In the second instance, in firms with no owners, governors and managers will expend more resources to obtain effective control of these unassigned rights than in firms where these rights are clearly vested in defined owners. Thus there must be compelling benefits from forgoing an ownership stake in order to overcome contract failure - for the simple reason that it excludes the very possibility of unexpected outcomes that give rise to the problem.

The expectation that much more explicit assignment is required of the various rights of control of the non-human assets in non-owned firms than in owned firms leads on naturally to a consideration of what those assets might be. Ben-Ner (1986) proposes a distinction between the residual control of the physical assets of a non-owned firm (e.g. buildings, plant, equipment, etc.) and the income streams they generated. In his view, the non-distribution constraint attends principally to the way in which the income streams are applied. The ownership of the assets need not be constrained to the same control and allocation arrangements as the income streams. This view is consistent with Hart and Moore's 'residual control of assets' view, whereby the profits of co-operatives are disbursed to members in proportion to their custom with the firm, whilst the residual control rights over the firm's assets may be exercised on the basis of membership or patronage. 
The distinction between income streams and residual assets in co-operatives and non-profit firms is further illustrated by McKinlay (1999) in relation to the dilemmas facing co-operatives under demutualisation. Where the distribution of the residual assets in the event of the dissolution of an owned firm is clear (to shareholders in proportion to their shareholding), unless there is a clearly articulated dissolution arrangement in the formal governance arrangements of a non-owned or co-operative firm (i.e. the constitution), then it is not immediately evident how the proceeds should be divided, even if it has been clear how the income streams should have been distributed (e.g. in proportion to custom). Further, some cooperatives have an asset lock, where the members have no claim on the residual assets, but on dissolution the assets are transferred to another cooperative or non-profit entity.

\section{Towards A Governance Taxonomy}

There is a number of different dimensions along which the nature of the firm's governance arrangements can be examined, determined by elements of the contracts of which comprising the firm. These dimensions lead towards a taxonomy of firm classifications, from which further insights can be gained to guide the normative task of governance design and the assessment of firm performance. We take as a starting point Hart \& Moore's and Ben-Ner's distinction between residual assets and income streams, and the difference between for-profit and nonprofit objectives to create Figure 1. 


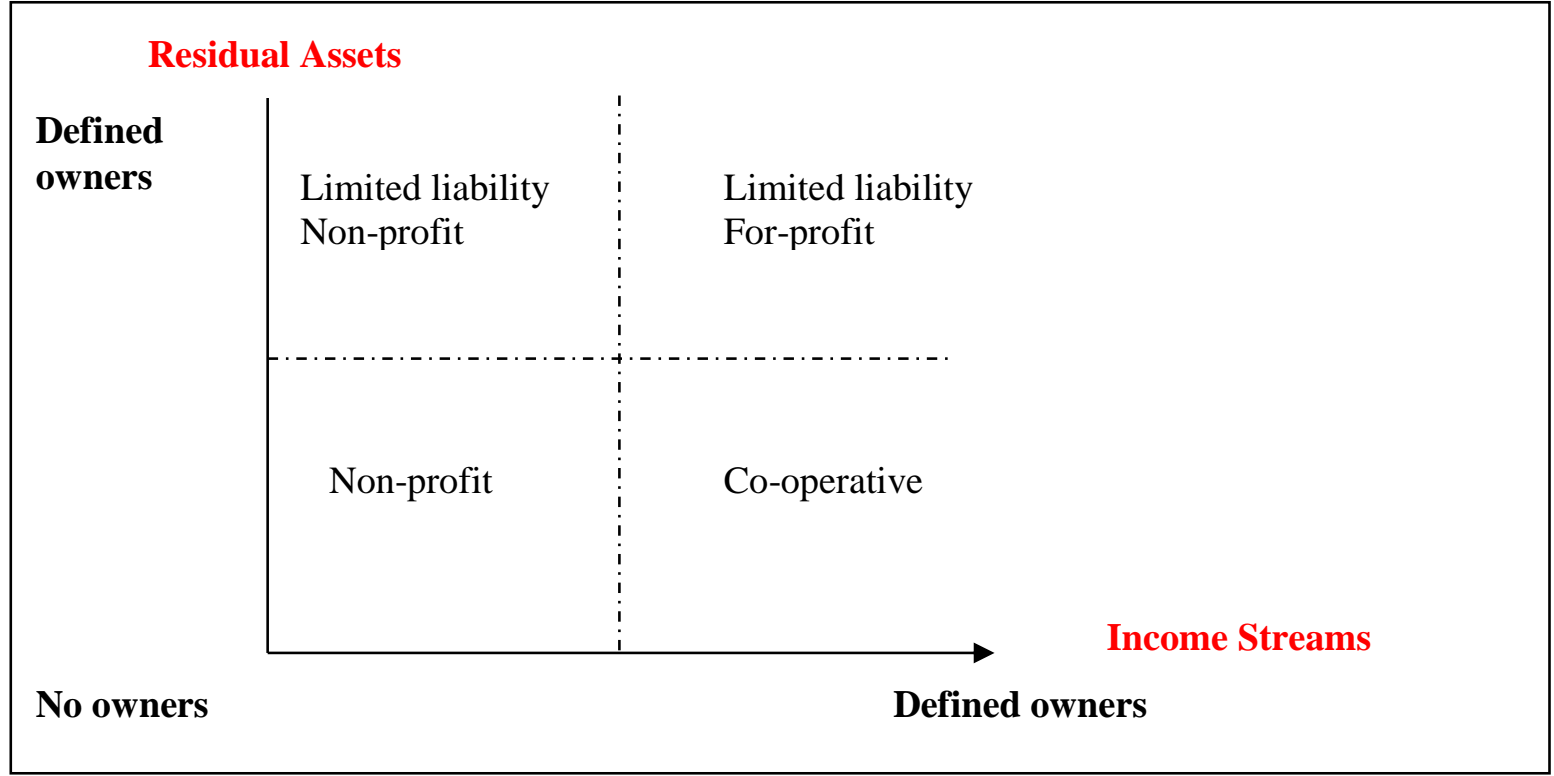

\subsection{The Ownership of Residual Risks}

Whereas the early Jensen, Meckling and Fama literature suggests the important distinctions are based on the separation of ownership and control, with shareholders being simply passive recipients, the Hansmann, Hart and Moore literature identifies that when the ownership of residual control of the assets which comprises the firm is vested in these shareholders, important differences arise. Whilst Hart and Moore have focused only on firms with defined ownership interests (shareholder-owned and co-operative firms), Hansmann identifies the case of a firm where there are no residual owners, and hence no owners - the classic 'non-profit'. Ben-Ner (1986) identifies that (at the very least) there are two distinct sorts of assets to be considered: the future income streams (profits) and residual assets (plant, equipment and retained earnings). The first question to be asked when examining a firm is therefore whether there are defined owners of the residual control rights to the assets of the firm as illustrated in Figure 1.

Standard for-profit firms with clearly defined owners of the residual control rights of both the income streams and residual assets, are shown in the top-right of Figure 1. By contrast, classic non-profit firms have no clearly defined owners of the residual control rights of the income streams or the residual assets, so sit at the bottom left. Sometimes firms are constituted with defined owners, but with a non-profit objective. They will sit on the top left of Figure 1: 
their defined owners (who may have contributed the assets of the firm initially, or stood as guarantors of loans) bear the residual financial risks and hence the residual control of those assets. However, the non-profit objective means that the firm's decision controllers must operate in line with the same sorts of fiduciary duties which bind the decision controllers of non-profit firms. Hence the decision controllers are not claimants to the residual control of the profit streams, even though they may have claims on the assets. Completing the matrix are cooperatives, on the bottom right of Figure 1. Co-operatives' members bear the residual risks associated with the income streams (profits) so profits of co-operative firms are distributed to the defined owners, that is, the members. Typically, co-operatives have no specific claims identified to the residual assets so, like non-profit firms, their claims sit at the non-owned end of the spectrum. ${ }^{2}$ However, the more clearly specified these rights become, the closer the cooperative moves towards the for-profit quadrant of the matrix in Figure 1.

\subsection{Which Stakeholders?}

Having identified the extent to which the relevant assets are 'owned', using Hansmann's theories, we now identify which stakeholding interests we expect to exert the relevant ownership interests (or in their absence, who the beneficial interests would be). This leads to the addition of a third dimension to the matrix, where the owning/controlling interests can be vested in either suppliers to the firm (equity owners, labour, other raw inputs) or consumers, as in Figure 2.

As noted by Chaddad and Cook (2004), while the traditional co-operative model is often portrayed as being quite separately
different from for-profit firms (and non-profit firms), a number of alternative models exist which could be described as being closer to for-profit or non-profit characterisations. 
Figure 2: Locus of Residual Control Rights by Firm Type and Stakeholding

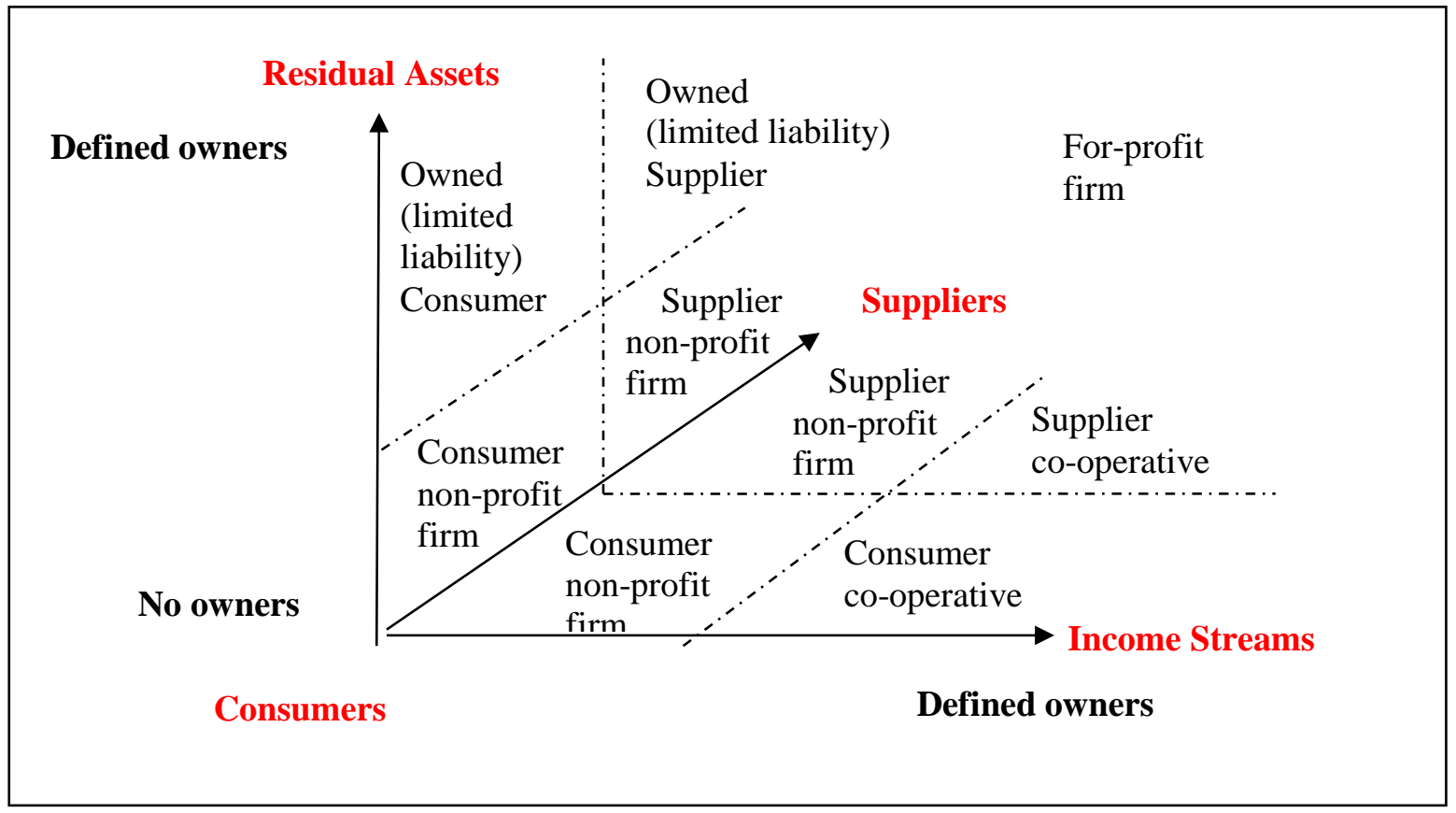

To illustrate the use of the three-dimensional matrix in Figure $2^{3}$, we observe a co-operative structured to reflect the interests of its members as consumers (for example a co-operative which delivers Continuing Professional Development to medical practitioners) occupying the front right of the Figure 2 cube. If it is a supplier co-operative (for example a co-operative of General Practitioners (GPs) who sell their services with a GP practice), it will sit at the back right of the cube in Figure 2. In both cases, the co-operative members have no claim on residual assets, but benefit either from income streams directly, or from reduced costs as a result of belonging to the club/co-operative.

Likewise, other firm types fit the cube in Figure 2. For example, a healthcare non-profit firm may be established to benefit the patients as consumers of services (e.g. a healthcare charity, bottom front left), or the doctors as suppliers (e.g. a professional association, bottom back left). In neither case are consumers or suppliers assumed to have any claim on residual assets or income streams.

Finally, at the top left of Figure 2 are pictured supplier- and consumer- owned nonprofit firms. In this respect, the members have a claim on the assets. However, they are unlikely

\footnotetext{
3 Note that, where cooperatives without an asset lock will also be in the space at the top left of Figure 2.
} 
to have a claim on the income streams due to the non-profit motive. A for-profit firm is depicted at the top right of Figure 2 as suppliers or consumers have a claim on assets and income streams.

\subsection{The Degree and Instruments of Control}

The three dimensional matrix provides a framework to conceptualise firm location in a space that describes the locus of residual control. However, as Hart and Moore identify, effective ownership pertains to the residual rights that are not already contractually assigned. As governance arrangements are contracts which are specifically intended to allocate control rights, then by definition the residual control rights comprising ownership are those that are not subject to governance contracts. Thus, it is imperative to understand first what rights have been contractually allocated, and the instruments by which the degree of control is exercised. We propose that this can be viewed along a continuum (see Figure 3).

Figure 3: Instruments Defining Income Streams and Residual Control Right Types in Firms:

\section{a Continuum}

\begin{tabular}{|c|c|c|c|c|c|}
\hline \multicolumn{6}{|c|}{ No owners } \\
\hline \multicolumn{2}{|c|}{$\begin{array}{l}\text { Type (see } \\
\text { Figure 2) }\end{array}$} & $\begin{array}{l}\text { Consumer or } \\
\text { supplier non- } \\
\text { profit firm } \\
\text { (e.g. charity) }\end{array}$ & $\begin{array}{l}\text { Non-profit firm or } \\
\text { cooperative } \\
\text { (supplier/ consumer) } \\
\text { (e.g. club) }\end{array}$ & $\begin{array}{l}\text { Supplier or } \\
\text { consumer } \\
\text { cooperative }\end{array}$ & $\begin{array}{l}\text { Limited Liability } \\
\text { company }\end{array}$ \\
\hline \multirow[t]{2}{*}{ 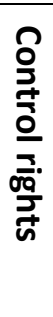 } & $\begin{array}{l}\text { Income } \\
\text { Streams }\end{array}$ & \multirow[t]{2}{*}{$\begin{array}{l}\text { No definable } \\
\text { claims nor } \\
\text { control rights } \\
\text { over either }\end{array}$} & No claims & $\begin{array}{l}\text { Partially } \\
\text { definable } \\
\text { claims }\end{array}$ & $\begin{array}{l}\text { Definable } \\
\text { claims over } \\
\text { income if for- } \\
\text { profit }\end{array}$ \\
\hline & $\begin{array}{l}\text { Residual } \\
\text { Assets }\end{array}$ & & $\begin{array}{l}\text { Definable control } \\
\text { rights }\end{array}$ & $\begin{array}{l}\text { Definable } \\
\text { control rights }\end{array}$ & $\begin{array}{l}\text { Definable } \\
\text { control rights }\end{array}$ \\
\hline \multicolumn{2}{|c|}{ Specified by: } & $\begin{array}{l}\text { Governance } \\
\text { instruments }\end{array}$ & $\begin{array}{l}\text { Individual } \\
\text { (contractual) } \\
\text { instruments }\end{array}$ & $\begin{array}{l}\text { Trading } \\
\text { instruments }\end{array}$ & $\begin{array}{l}\text { Shareholding } \\
\text { instruments }\end{array}$ \\
\hline
\end{tabular}

The continuum in Figure 3 moves from a consumer non-profit with 'no owners' on the left, where there are no obvious residual owners of the firm's assets, to a limited liability company with 'defined owners' on the right. Hence, both the residual owners' identity, and the allocation 
of the residual rights, are defined by the shareholding instrument. There is a range of increasingly well-defined instruments via which the control rights are specified.

A non-owned firm (on the extreme left) has no legal owners. The lack of clarity about ownership increases the need to use of contractual instruments to specifically assign control rights relative to a firm with fully defined owners. We could expect that, all else held equal, the non-owned firm's governance arrangements will rely much more strongly upon contracts than the owned firm (relying on alignment of share ownership and residual control), to ensure that the control rights are exercised in the interests of the beneficial owners.

Moving to the right on Figure 3, the identification of a specific ownership interest, for example a supplier non-profit with defined members, reduces uncertainty relative to a charity where beneficial owners are identified as a population rather than specific individuals. Supplier non-profit members retain residual rights of control (from their membership), but in the nonowned case, the allocation of the risks and control is based purely on the basis of member/voting. Residual control is now allocated through a crude contractual instruments and no direct nexus between control and the rights to residual assets or income streams.

For a direct nexus between the control rights and beneficiary status, and further to the right in Figure 3, one can link the individual's membership status with some other metric - for example, a trading activity. Trading is the individual's market interaction with the firm, either as a consumer, or a supplier providing inputs. This structure is the classic consumer- or supplierowned cooperative firm. Whilst clarity about the residual control rights is greatly improved over the non-owned firm, a potential tension remains between the control exerted by membership interests and the trading instruments via which benefits are disbursed. Myers and Scott Cato (2011) note that the co-operative ownership model fits General Practitioner (GP) practices well, as these suppliers may exert greater control and influence over government funders as a cooperative than individually. Such a cooperative also allows GPs to provide around-the-clock cover for patients. 
Ultimately, if the market interaction is to supply capital to the firm (as per Hansmann), then a position has been reached where control and residual benefit allocation have become perfectly united via the share instrument of shareholding (as shown on the right hand end of Figure 3).

\section{Applying the taxonomy: New Zealand's primary healthcare reforms}

To assess the usefulness of this taxonomy for understanding the allocation of residual control amongst nonstandard firms, we examine the New Zealand primary healthcare reforms. In order to respond to its commitments under the Alma Ata Declaration (World Health Organization, 1978), the New Zealand government instigated a Primary Health Care Strategy (King, 2001) in 2002, substantially increasing funding to those non-profit providers that formed as Primary Health Organizations (PHOs). Equitable access and affordability for citizens were priorities for this funding which was based on a population-health basis with capitation and responding to community needs, rather than individual charges to patients. In addition, favouritism towards community control was indicated, as all PHOs were required to include both community and provider representatives on their governing boards. The impetus for the non-profit firm was to "ensure that funds for healthcare are not diverted into private profits" (King, 2002), There was no specific requirement that the firms have owners or not. Nor did the policy preclude the ability for non-profit PHOs to enter into contracts with for-profit providers for the delivery of care indeed, this was anticipated to be the most likely scenario in order to ensure the ready supply of primary health care. Further, the reforms required PHOs to 'include their communities in their governing processes' with 'all providers and practitioners ... involved in the organization's decision-making rather than one group being dominant' (King, 2001, p.viii), thus suggesting that these PHOs trend towards consumer-controlled firms (or at least demonstrate a 'mixed governance' model where all stakeholders had apparently equal representation, so that none would be able to acquire effective control).

Prior to the reforms, government primary health care funding principally subsidised the GP visits of lower socio-economic patients. A wide variety of organisational forms existed in 
the New Zealand primary healthcare sector (as shown in Figures 4 and 5). The industry consisted mainly of self-employed GPs operating as for-profit businesses (at the right hand end of Figure 4), but due to funding incentives in the early 1990s, by 2002 (the effective date of the reforms), $84 \%$ of GPs were members of primary care organizations formed for the purposes of contracting with the Government. Of these $80 \%$ were also members of Independent Practitioner Associations (IPAs) (Controller and Auditor-General, 2002), supplier-controlled firms that enabled GPs to benefit from medical research, continuing professional development and, most importantly a vehicle through which GPs could jointly bargain with the government for contracted bulk funding and lobby for additional resources. Contemporaneously, 3\% of GPs worked in primary care organizations contracting independently with the government, $15 \%$ in loose networks and 2\% were in non-profit consumer-controlled firms (Controller and AuditorGeneral, 2002). These latter organizations served comparatively homogeneous populations whose preferences differed from customers of self-employed GPS and included, for example, union and $i w i^{4}$ health clinics with a strong non-profit focus (see centre and left of Figure 4). Further, consumer-controlled rural health clinics had developed where the costs of ownership for a rural GP were too high and the community took ownership of the rural practice, operating as charities in order to ensure continuation of a service in a remote area (left hand side of Figure 4).

Figure 4: Instruments of Residual Control Right Types - pre policy change

\begin{tabular}{|c|c|c|c|c|c|}
\hline \multirow{2}{*}{ No owners } & Charities & $\begin{array}{c}\text { Iwi } \\
\text { Authorities }\end{array}$ & $\begin{array}{l}\text { Union } \\
\text { Clinics }\end{array}$ & IPAs & $\begin{array}{l}\text { Private GP } \\
\text { practices }\end{array}$ \\
\hline & $\begin{array}{l}\text { Contractual } \\
\text { Instruments }\end{array}$ & $\begin{array}{l}\text { Individual } \\
\text { Instruments }\end{array}$ & $\begin{array}{c}\text { Trading } \\
\text { Instruments }\end{array}$ & $\begin{array}{l}\text { Shareholding } \\
\text { Instruments }\end{array}$ & \\
\hline
\end{tabular}

$4 \quad$ Iwi is the Maori word that corresponds with the concept of a tribe. 
As shown in Figure 5 (an extension of Figure 3), most IPAs operated as co-operatives, where the GPs were the customers of their services (mainly collective contracting for government contracts) in line with the model supported by Myers and Scott Cato (2011).

Figure 5: Locus of Residual Control Rights and Stakeholding - pre policy change

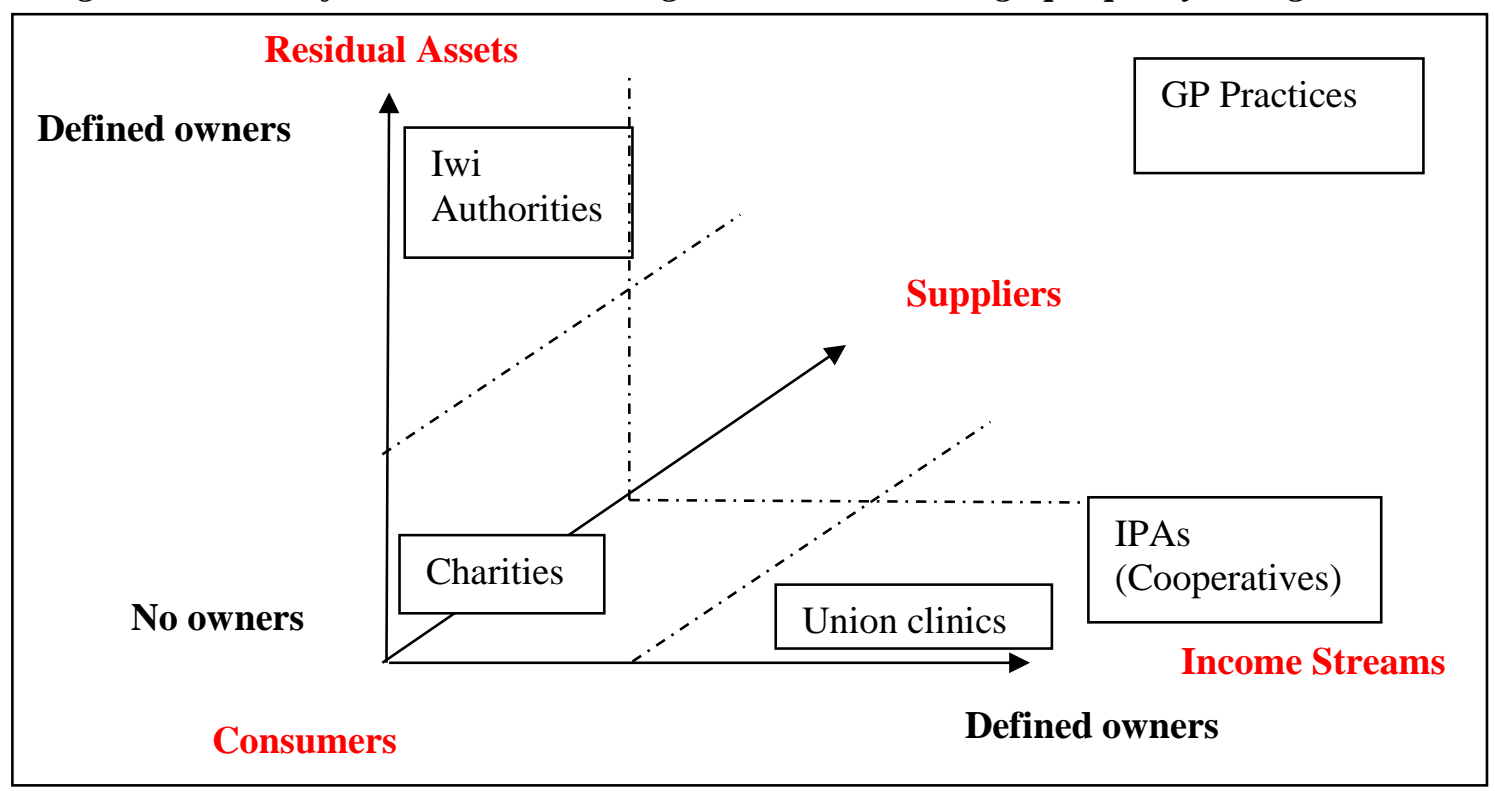

The PHOs created under the reforms accordingly emerged from the different firms existing prior to the policy's enactment. The non-profit directive required that all PHOs be oriented on the left-hand side of Figure 1 (and Figure 4) and include a wide range of stakeholders in decision-making. This would therefore place them towards the front of Figure 2 (and Figure 5) to include consumers as well as suppliers in governance. Those firms previously established as charities had few difficulties in adapting to the NZPHCS's requirements, as they were non-profit already, and many had consumer and provider representation on their boards. This is shown by their position straddling the supplier-consumer continuum in Figure 5. The trade union co-operatives (union clinics) and iwi authorities already had strong consumer orientation. However, with defined ownership stakes in respect of income streams, co-operative unions could not form as PHOs directly. In most part, cooperatives resolved the funding issues by affiliating contractually with PHOs formed from other origins and maintaining separate operational control. Iwi quickly developed operational collaborations and maintained direct contractual relationship with government funders. 
The taxonomy allow us to identify significant differences in the allocation of control that emerged in the PHOs formed to satisfy the strategy. Even though they are subject to essentially the same government contracts, different allocations of the balance of residual control resulted in different understandings of what it means to be 'non-profit'. The most significant changes following the reforms came in respect of the PHOs formed to affiliate (contract) with GPs. The IPAs were already established as (GP) consumer co-operatives, and were essentially non-profit. Nevertheless, in general, non-union and non-iwi GP practices (supplier cooperatives) did not fit the government requirement, as they were for-profit firms. As substantial increased funding was available to appropriately constituted PHOs, the rising competition from community-controlled PHOs, provided strong incentives for self-employed GPs to join or form PHOs as quickly as possible. Thus, many GPs encouraged IPAs to form 'non-profit' supplier cooperatives to enable them to access funding, but continue to operate their businesses as before. However, traditionally GP Cooperatives "have a professional culture that may make alliances with community and consumer groups difficult to conceive, develop, and maintain" (Schlaff, 2005, p.833).

As shown in Figure 6, most IPAs formed as charitable trusts, but with the allocation of control rights in large part reflecting their supplier origins. Hence they are positioned on the 'supplier' side of Figure 6. However, a significant subset of IPAs formed as limited liability companies (albeit with non-profit objectives) with IPA members as shareholders (see top right of Figure 6). Importantly, neither limited liability nor IPA Trusts engage in supplying care directly to patients, but persist with non-integrated contracting of care to GPs and other providers. This is consistent with the observation that GPs owning non-contractible human and practice capital prefer for the most part not to integrate with other providers, but to retain control of the contracts that govern access to their funding.

By comparison, the PHOs that have formed around consumer-oriented $i w i$ Trusts and local Charitable Trusts are more likely to be operating as integrated care provider entities, hiring doctors and nurses as employees and directly contracting with the government entities for funding. In part, these firms supply care in geographic locations where there is a 'missing 
market' for GPs (e.g. rural locations) or to specific customer groups requiring care delivered in a specific way that limits the scope of GP practice such that GPs are reluctant to develop the specific human capital unless employed (e.g. care to specific ethnic groups).

Figure 6: Locus of Residual Control Rights and Stakeholding in non-profit PHOs.

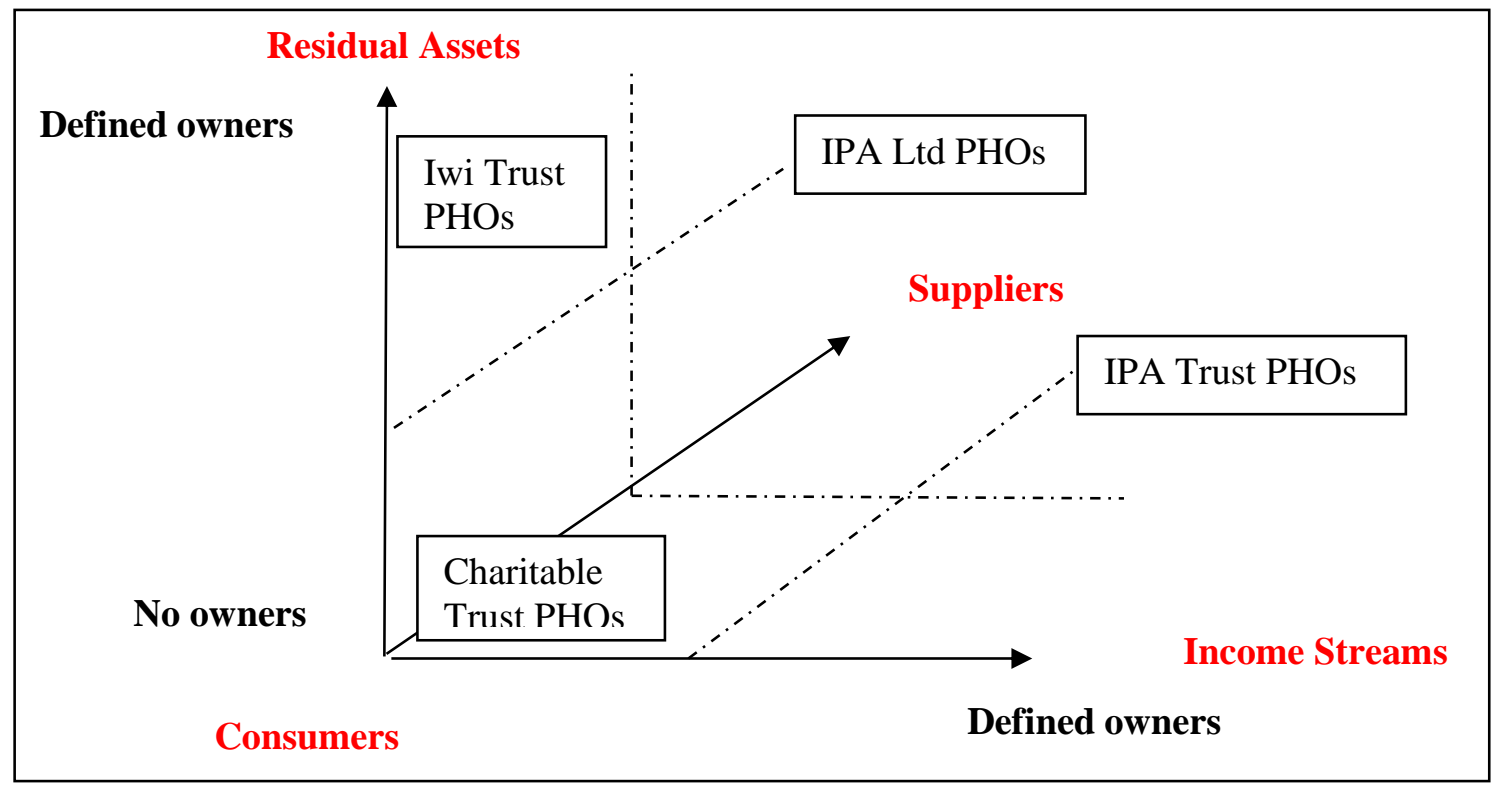

Despite the variety observed in Figure 6, we argue that the reforms intended PHOs to have an organisational form that positioned them on the left hand side of Figure 6 as non-owned non-profit or limited liability non-profit firms, hence our argument that the policy did not achieve its aim. Instead of consumer- or mixed-governance where all stakeholder had apparently equal representation (King, 2001) Table 1 shows a predominance of suppliermanaged firms rather than a variety of decision makers as the policy required. Table 1 provides a snapshot of the percentage of board members that represent GP/supplier interests in all of the PHOs (which are listed in Appendix 1). It can be seen that supplier and mixed-origin PHOs have, on average, $60 \%$ more GPs/suppliers involved in governance, than consumer origin PHOs. We argue that, by failing to consider the residual rights (the form), and by concentrating only on structure (a non-profit) the PHC reforms have missed a vital opportunity to meet their goals to stop diversion of government funds to private profits and to engage a wide diversity of stakeholders in governance. 
Table 1: Percentage of board members representing supplier (GP) interests

\begin{tabular}{|c|c|c|c|}
\hline & Consumer Origin & Supplier Origin & Mixed Origin \\
\hline Average & $\mathbf{2 8 . 6 \%}$ & $\mathbf{4 6 . 1 \%}$ & $\mathbf{4 5 . 8 \%}$ \\
\hline Lowest & $\mathbf{0 \%}$ & $\mathbf{3 0 \%}$ & $\mathbf{1 4 \%}$ \\
\hline Highest & $\mathbf{5 0 \%}$ & $\mathbf{7 5 \%}$ & $\mathbf{7 8 \%}$ \\
\hline
\end{tabular}

Appendix 1 provides a breakdown of the PHOs by consumer-type and by producertype. This shows that consumer-origin non-owned non-profit firms outnumber the owned nonprofit firms and over $90 \%$ of the New Zealand population is registered to receive services through an IPA-origin (supplier-focused) PHO. However, in terms of producer-origin firms, while the number and reach of non-owned non-profit firms is greater than the owned non-profit firms, the power of the latter is likely to be greater, as a small number of firms have the majority of patients.

Whilst the NZPHCS required PHOs to be established as non-profit organisations so as to "ensure that funds for healthcare are not diverted into private profits" (King, 2002), the extent to which the effective control of PHOs is vested in supplier-oriented entities contracting with for-profit GPs is unlikely to have achieved this objective. Instead, with effective control biased towards suppliers, then residual control is also likely biased in that direction. The analysis suggests that, instead of specifying a non-profit objective function, and in order to direct government funds towards healthcare provided to patients, it would have been more useful to have specified an ownership restriction (e.g. requiring consumer-oriented firms) or imposed governance controls limiting the influence of a specific group of stakeholders (e.g. suppliers).

The union co-operatives present an interesting anomaly. Whilst strongly consumeroriented, and arguably well-positioned to integrate government contracting with care delivery, they have for the most part remained as stand-alone care providers, contracting with IPA-PHOs for their funding. Although these arrangements may appear to dilute consumers' interests at the PHO decision-making table, they were likely too small in size to manage the contracting 
required of PHOs. Hence they have compromised by joining PHOs, but such cooperatives have not compromised their unique character when it comes to governing their own firms, maintaining their unique care provider character.

\section{Discussion and Conclusion}

This paper was motivated by the dearth of Organizational Economics research into nonstandard entities (highlighted by Gibbons \& Roberts, 2012) and the need to provide a framework for identifying differences in residual ownership and control (as identified by Aghion et al., 2014). The paper has analysed prior literature on the theory of the firm and the related governance arrangements that inform us about the arrangements for governing and contracting with firms having nonstandard ownership. While Berle and Means (1932) limited their discussion to forprofit (publicly listed) firms, the greatest number of organizations are small and there is a great variety of different ownership models in this current age. Jensen and Meckling (1976) focused on the contractual exchange within the firm, but were unable to explain why firms would arise with no owners. Nevertheless, Fama and Jensen's (1983a, 1983b) arguments of the need to separate decision-making from decision implementation (management and governance) can be applied more broadly than merely for-profit firms.

The incomplete contracting framework proposed by Grossman and Hart (1986) and extended in recent years sheds a great deal of light on particular issues relating to firms: notably, the extent to which activities will be integrated within them, and the extent to which control will be centralised and controlled by residual claimants, or decentralised and entrusted to managers. However, this literature presumes that residual control is exerted by residual owners. It does not explain why some firms have nonstandard ownership arrangements, and allocate residual control to individuals with no or constrained ownership stakes. Particularly, it does not provide a good explanation for classic non-owned non-profit firms.

Hansmann (1996; 2008. 2012), building on both the agency theory and incomplete contracting theories of the firm, suggests that the most efficient organisational form (for-profit, 
co-operative or non-profit) will evolve endogenously, depending on contractual arrangements and the costs of these. However, Hart and Moore $(1990,1996,1999)$ argue that transaction costs can provide a partial theory only due to the inability to contract all of a firm's requirements, while Evans, et al. (2012) maintain the boundaries of a firm are determined by the efficiency of allocating the residual rights of control to different parties.

In this paper we have extended these arguments and those of Hart and Moore (1996) and Ben-Ner (1986), which analysed different ways in which nonstandard firms contract differently for different assets. Specifically we have considered residual control of assets and income streams to derive a taxonomy of governance for managing these residual risks. In particular, we have considered which stakeholders may be important (consumers or suppliers) and also the types of instruments that would be used in this control continuum. We have illustrated the taxonomy with an example from primary healthcare in New Zealand, where, prior to reforms, a variety of firm-types existed.

However, following reforms that required PHOs to be non-profit making and to include diverse stakeholders in decision-making, these firms coalesced mainly into non-owned types (as also evident in the UK - Allen et al., 2011). As such, control is either in the hands of the consumer or the hands of the supplier. When suppliers are governors, they are more likely to manage the income flows so as to extract profits for the suppliers. This is at odds to the requirement of the reforms to stop public funds being diverted to private profits (King, 2001); it is also less likely that consumers will be actively involved in decision-making as required under the reforms. We argue that this outcome has not achieved the reform's aims. A non-profit objective alone is no substitute for a consumer co-operative structure which appeared to be the aim of the policy change. Indeed, by relying on governance instruments, where decision-makers have no pecuniary interest (control rights or definable claims), it is far from clear how any ex post negotiation will reliably reflect the interests of suppliers, consumers or the funder, unless it was anticipated ex ante.

As noted, Ben-Ner (1986) states that non-profit organizations are more likely to operate in trust goods such as health, and Allen et al. (2011) agree that government prefers to fund 
them. It is expected that non-profit providers will deliver higher quality services to unprofitable patients (Allen et al., 2011, Kanaya et al., 2015), yet in Japan, patients do not perceive citizen(consumer)-driven non-profit providers to be as reliable as for-profit providers. On the contrary, Allen et al. (2011) notes that the UK National Health Service seeks to support startup client(consumer)-led non-profit providers to provide diversity. However, there is no analysis of their performance compared to for-profit providers (Allen et al., 2011).

In this paper we have drawn out not just the consumer/supplier split between providers, but also whether the organization has owners or not. This theoretical extension could be used to empirically analyse contracting out in health care. Specifically, does performance (service and/or financial) differ depending on who leads the non-profit provider - the consumer or supplier? Further, does performance (service and/or financial) differ depending on whether the provider has owners or not?

While the case study offered in this paper may be limited contextually to the New Zealand health care sector, we suggest that the taxonomy developed here enables more structured and principled empirical analysis of how nonstandard allocation of residual control and ownership may play out in both for-profit and non-profit firms, under the assumptions of both agency and contractual incompleteness theories of the firm. We believe that the taxonomy provides a means of classifying firms to enable large-scale empirical analysis to be undertaken that have so far eluded scholars of incomplete contracting. We hypothesise that performance will differ and that it is evident from our case study that policy-makers and funders should be aware of these differences. This would enable them to define the governance arrangements which they are prepared to regulate and fund. Organizational owners will also seek more granular information to be sure that their organizational structures are suitable for the performance sought. We contend that the taxonomy enables further empirical analysis because it allows researchers to control for many of the subtle between-firm distinctions that have historically limited the use of this approach. 


\section{REFERENCES}

AGHION, P., BLOOM, N., \& VAN REENEN, J., 2014, 'Incomplete contracts and the internal organization of firms', The Journal of Law, Economics and Organization, 30 (S1), 3763.

AGHION, P., DEWATRIPONT, M., LEGROS, P., \& ZINGALES, L., 2014, 'Foreword', The Impact of Incomplete Contracts on Economics, New York: Oxford University Press.

ALCHIAN, A. A. \& DEMSETZ, H., 1972, 'Production, information costs, and economic organization', The American Economic Review, 62 (5), 777-795.

Allen, P., BARTLETT, W., PEROTIN, V., ZAMORA, B. \& TURNER, S., 2011, 'New forms of provider in the English National Health Service', Annals of Public and Cooperative Economics, 82 (1), 77-95.

BARNETT, R. \& BARNETT, P., 2004, 'Back to the future? Reflections on past reforms and future prospects for health services in New Zealand', GeoJournal, 59, 137-147.

BEN-NER, A., 1986, 'Nonprofit Organizations: Why do they exist in market economies?' In S. Rose-Ackerman (Ed.), The Economics of Nonprofit Institutions: Studies in Structure and Policy (pp. 94-113). New York: Oxford University Press.

BERLE, A. \& MEANS, G., 1932, The modern corporation and private property. New Brunswick, New Jersey: Transaction Publishers.

BOLTON, P., 2014, 'Corporate finance, incomplete contracts and corporate control', The Journal of Law, Economics and Organization, 30 (S1), 64-81.

CHADDAD, F. R. \& COOK, M.L., 2004, 'Understanding New Co-operative Models: An Ownership-Control Rights Typology', Review of Agricultural Economics, 26 (3) 349360.

COASE, R. H., 1937, 'The Nature of the Firm', Econometrica. 4 (16): 386-405.

CONTROLlER AND AUDITOR-GENERAL, 2002. Purchasing Primary Health Care Provided in General Practice, Wellington: Office of the Auditor-General 
DEMSETZ, H., 1967, 'Toward a theory of property rights', The American Economic Review, 57 (2), 347-359.

DESSEIN, W., 2014. 'Incomplete contracts and firm boundaries: New directions',. Journal of Law, Economics, and Organization, 30(SUPPL. 1), 13-37.

EVANS L., GUTHRIE G. \& QUIGLEY N., 2012, 'Contemporary Microeconomic Foundations for the Structure and Management of the Public Sector', Treasury Working Paper Series 12/01, New Zealand Treasury.

FAMA, E. F. \& JENSEN, M. C., 1983a, 'Separation of Ownership and Control', Journal of Law and Economics, 26 (2), 301-325.

FAMA, E. F. \& JENSEN, M. C., 1983b, ‘Agency Problems and Residual Claims', Journal of Law and Economics, 26 (2), 327-349.

GIBBONS, R., \& ROBERTS, J., 2012, 'Introduction', The Handbook of Organizational Economics. Princeton University Press.

GLAESER, E.L. \& SCHLEIFER, A., 2001. 'Legal Origins', Harvard Institute of Economic Research, Working Paper 1920, Cambridge, MA.

GROSSMAN, S. J. \& HART, O. D., 1986, 'The costs and benefits of ownership: A theory of vertical and lateral integration', The Journal of Political Economy, 691-719.

HANSMANN, H., 1980, ‘The role of non-profit enterprise', The Yale Law Journal, 89 (5), 835901.

HANSMANN, H., 1996, The ownership of enterprise. Cambridge, Massachusetts: Harvard University Press.

HANSMANN, H., 2008, 'Firm Ownership and Organizational Form', SSRN Working Paper 2101327

HANSMANN, H., 2012, 'Firm Ownership and Organizational Form', Chapter 22 (pp 891-917) in Gibbons, R., \& Roberts, J. (eds) 2012, The Handbook of Organizational Economics. Princeton University Press.

HART, O., 2003, 'Incomplete Contracts and Public Ownership: Remarks, and an Application to Public-Private Partnerships', The Economic Journal, 113 (486), C69-C76. 
HART, O. \& HOLMSTROM B., 2010, ‘A Theory of Firm Scope’, The Quarterly Journal of Economics, $\mathrm{CXV}(2), 715-753$.

HART, O. \& MOORE J., 1990, 'Property Rights and the Nature of the Firm', Journal of Political Economy, 1119-1158.

HART, O. \& MOORE, J., 1996, 'The governance of exchanges: Members' cooperatives versus outside ownership', Oxford Review of Economic Policy, 12 (4), 53-69.

HART, O. \& MOORE, J., 1999, 'Foundations of incomplete contracts', Review of Economic Studies, 66 (1), 115-138.

HOWELL, B. \& CORDERY, C., 2013, 'From Providers to PHOs: an institutional analysis of nonprofit primary healthcare governance in New Zealand', Journal of Public Budgeting, Accounting \& Financial Management, 25 (1), 4-40.

IOSSA, E. 7 MARTIMORT, D., 2015, "The simple microeconomics of Public-Private Partnerships", Journal of Public Economic Theory 17 (1), 4-48.

JENSEN, M. C., 2001, 'Value maximisation, stakeholder theory, and the corporate objective function', European Financial Management, 7 (3), 297-317.

JENSEN, M. C., 1993, 'The modern industrial revolution, exit, and the failure of internal control systems', The Journal of Finance, 48 (3), 831-880.

JENSEN, M. C. \& MECKLING, W. H., 1976, 'Theory of the firm: Managerial behavior, agency costs and ownership structure', Journal of Financial Economics, 3 (4), 305-360.

KANAYA, N., TAKAHASHI, H. \& SHEN, J., 2015, 'The market share of non-profit and forprofit organizations in the quasi-market: Japan's long-term care services market', Annals of Public and Cooperative Economics, 86 (2), 245-266.

KING, A., 2001, The Primary Healthcare Strategy. Ministry of Health. Available online http://www.moh.govt.nz/moh.nsf/0/7BAFAD2531E04D92CC2569E600013D04/\$Fil e/PHCStrat.pdf.

KOWALSKI, P., BÜGE, M. \& SZTAJEROWSKA, M., 2013, State-Owned Enterprises: trade effects and policy implications. Paris: OECD. 
MCKINLAY, P., 1999, Public ownership and the community. Wellington, New Zealand: Brebner Print Limited.

MILGROM P. R. \& ROBERTS, J., 1992, Economics, organization and management. PrenticeHall International.

MOE, T., 2012. 'Delegation, control and the study of public bureaucracy', The Forum 10(2), $1-45$.

MYERS, J. \& SCOTT CATO, M., 2011, 'From 'personal' to 'mutual': exploring the opportunities for co-operative and mutual forms of ownership and governance in the design and delivery of social and public services' in The Third Sector Dialogues in Critical Management Studies Vol 1 Hull, R., Gibbon, J., Branzei, O and Haugh, H. Eds. pp. 33-52.

PRICE, D., POLLOCK, A.M. \& BRHLIKOVA, P., 2011, 'Classification problems and the dividing line between government and the market: an examination of NHS Foundations Trust classification in the UK', Annals of Public and Cooperative Economics, 82 (4), 455-473.

SACCHETTI, S. \& TORTIA, E., 2015, 'The extended governance of cooperative firms: interfirm coordination and consistency of values', Annals of Public and Cooperative Economics, forthcoming.

SCHLAFF, A.L., 2005, 'Lack of national primary care organization partnerships with community groups to promote healthcare reform', American Journal of Public Health, $95(5), 832-834$.

THORNTON, J. \& CAVE, L., (2010). 'The effects of organizational form in the mixed market for foster care', Annals of Public and Cooperative Economics, 81 (2), 211-245.

WILLIAMSON, O. E. 1979, 'Transaction-cost economics: the governance of contractual relations', Journal of Law and Economics, 22 (2), 233-261.

\section{APPENDIX 1: PHO Origins 2003-2004}




\section{Consumer Origins*}

Non-owned Non-profit

AuckPAC Health Trust Board

Coast to Coast PHO

Hauora Hokianga Integrated PHO

Hauraki PHO

Hurunui Kaikoura PHO

Kaipara Care Incorporated

Langimalie Health Clinic Tongan

Mangere Community Health Trust

Maori PHO Coalition

Nga Mataapuna Oranga

Ngati Porou Hauora Incorporated

North Waikato PHO

Otaki Primary Health Organisation Trust

Peoples Healthcare Trust

Piki te Ora ki Te Awakairangi

Ropata Community PHO

South East \& City PHO

Tamati Whangai PHO

TaPasefika Health Trust

Taumata Hauora Trust

Te Ao Hou Primary Health Organisation

Te Kupenga A Kahu Trust

Te Kupenga O Hoturoa Charitable Trust

Te Tihi Hauora o Taranaki

Tihewa Mauriora Charitable Trust

Tipaka Moana PHO Trust

Wairoa District Charitable Health Trust

Wangaroa Primary Health Organisation

Total Enrollees

Total Enrollees in consumer origin Non-profit

\section{\#Enrollees}

30,044 Horowhenua PHO Ltd

11,910 Porirua Health Plus Limited

6,633 Tararua PHO Limited

7,199 Te Tai Tokerau PHO Ltd

12,278 Tumai mo te Iwi Inc

12,008

6,039

11,827

7,328

8,685

12,579

8,878

5,975

5,935

12,248

16,186

9,543

4,563

18,768

5,492

7,176

6,870

19,364

6,140

8,729

6,523

8,630

318

277,868
\# Enrollees

23,843

12,857

15,882

41,468

45,056

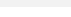

$\begin{array}{lrlr} & \text { Producer Origins* } & \\ \text { Canterbury Community PHO } & 5,082 & \text { Auckland PHO Ltd } & 15,636 \\ \text { Capital PHO } & 127,559 & \text { Central Otago PHO Ltd } & 37,837 \\ \text { East Health Trust } & 69,851 & \text { Dunedin City PHO Ltd } & 79,065 \\ \text { Eastern and Northern Southland PHO } & 16,920 & \text { Eastern Bay of Plenty PHO Ltd } & 31,463 \\ \text { HealthWest } & 149,365 & \text { Hawkes Bay PHO Ltd } & 131,336 \\ \text { Kapiti PHO } & 33,219 & \text { Lake Taupo PHO Ltd } & 33,821 \\ \text { Karori PHO Trust } & 12,668 & \text { Marlborough PHO Ltd } & 38,379\end{array}$


Kawerau Interim PHO

Manaia Health PHO

MidValley Access PHO

Mornington PHO

Waiora Healthcare Trust

Wairarapa Community PHO Trust

Wakatipu PHO

West Coast PHO

Western Bay of Plenty PHO

Whanganui Regional PHO

Total Enrollees

Total Enrollees in producer-origin Non-profit
7,208 Nelson-Tasman PHO Ltd

74,244 Pinnacle Incorporated

20,319 Procare Network Auckland Ltd

14,595 Procare Network Manukau Ltd

10,652

37,159

11,644

25,396

125,836

47,760

$1,833,777$

$1,442,328$

Notes: * The allocation of PHOs into consumer and supplier as well as owned and non-owned has been undertaken as accurately as possible in light of the data available.

Source: Ministry of Health and Ministry of Health (2005). [Online]. Available at www.moh.govt.nz/moh.nsf/wpg_index/-Primary+Health+Care+Establis hed+PHOS. 